\title{
Fairness in Transport Policy: A New Approach to Applying Distributive Justice Theories
}

\author{
Edward Randal ${ }^{1, *}\left(\mathbb{D}\right.$, , Caroline Shaw ${ }^{2}$, Alistair Woodward ${ }^{3}$, Philippa Howden-Chapman ${ }^{1}(\mathbb{D}$, \\ Alex Macmillan ${ }^{4}$, Jamie Hosking ${ }^{3}{ }^{(D}$, Ralph Chapman ${ }^{5}{ }^{\circledR}$, Andrew M. Waa ${ }^{6}$ \\ and Michael Keall ${ }^{1}$ (D) \\ 1 NZ Centre for Sustainable Cities, Department of Public Health, University of Otago, \\ Wellington 6242, New Zealand; philippa.howden-chapman@otago.ac.nz (P.H.-C.); \\ michael.keall@otago.ac.nz (M.K.) \\ 2 Department of Public Health, University of Otago, Wellington 6242, New Zealand; \\ caroline.shaw@otago.ac.nz \\ 3 School of Population Health, The University of Auckland, Auckland 1142, New Zealand; \\ a.woodward@auckland.ac.nz (A.W.); jamie.hosking@auckland.ac.nz (J.H.) \\ 4 Department of Preventive and Social Medicine, University of Otago, Dunedin 9054, New Zealand; \\ alex.macmillan@otago.ac.nz \\ 5 NZ Centre for Sustainable Cities, School of Geography, Environment and Earth Sciences, \\ Victoria University of Wellington, Wellington 6140, New Zealand; ralph.chapman@vuw.ac.nz \\ 6 Eru Pōmare Māori Health Research Centre, Department of Public Health, University of Otago, \\ Wellington 6242, New Zealand; andrew.waa@otago.ac.nz \\ * Correspondence: edward.randal@otago.ac.nz
}

Received: 6 November 2020; Accepted: 30 November 2020; Published: 3 December 2020

check for updates

\begin{abstract}
The transport system influences everyone's wellbeing on a daily basis. These impacts are both positive and negative and are borne directly and indirectly at a range of spatial and temporal scales and across different groups in society. Furthermore, they are often distributed unfairly and the people who are least able to use transport networks frequently bear the greatest costs. People also have various transport needs and these needs change throughout their lives. Due to these complexities, there is no straightforward answer as to how we should provide transport fairly. Policies and actions to decarbonise the transport system are urgently needed, but their equity effects are also important. We give a brief overview of distributive justice and equity in transport literature. We then develop a conceptual framework of distributive justice and a set of four principles to guide the application of the framework to transport policy. We then apply these to recent transport policies in Aotearoa/New Zealand, a country that shares common features with most highly motorised countries. We apply the Capabilities Approach to transport policy in a novel way that conceptualises transport policy as a social conversion factor which influences people's ability to convert resources and opportunities into the things ('beings and doings') that they have reason to value. The consideration of transport policy as a conversion factor, rather than focusing on a specific capability, emphasises the role of transport policy as a promoter of a wide range of capabilities and highlights the inequitable distribution of positive and negative effects on people's health and wellbeing. It also illuminates issues of power structures and procedural fairness in transport policy that are otherwise not covered by distributive justice approaches. Taking a broader view of distributive justice theory in transport provides a clearer picture of the impacts of transport on wellbeing and provides theory-based guidance on the actions to improve transport justice that can be readily integrated into existing policy institutions.
\end{abstract}

Keywords: transport policy; capabilities approach; wellbeing; health; equity; distributive justice 


\section{Introduction}

There is currently an urgent global need to address inequalities. Many governments around the world have committed to the United Nations' Sustainable Development Goal 10 to achieve reduced inequalities:

Inequalities based on income, sex, age, disability, sexual orientation, race, class, ethnicity, religion and opportunity continue to persist across the world, within and among countries. Inequality threatens long-term social and economic development, harms poverty reduction and destroys people's sense of fulfilment and self-worth. This, in turn, can breed crime, disease and environmental degradation. [1] (p. 1)

This statement establishes the United Nations' position that inequalities across populations based on individual human characteristics and inequalities of opportunity are both harmful and dangerous, as well as being fundamentally unfair or unjust (for clarity we will use the term inequity from this point on to refer to inequalities that are unfair and avoidable). The drivers of these inequities are social, economic and cultural structures and systems that ultimately result in poorer health outcomes and reduced quality of life for the disadvantaged [2]. One important system that drives inequities is the transport system [3].

Aotearoa/New Zealand, like many of the developed nations that have committed to the Sustainable Development Goals, has a transport system that is typical of highly car-oriented societies. This is characterised by high expenditure on roads and private vehicle infrastructure, low investment in public and active transport, sprawling low-density urban form, high levels of congestion and road injury, and low levels of physical activity. These are aligned with the other social, cultural and environmental privileges afforded to cars and their use that are key components of a 'System of Automobility' [4]. A recent econometric study that analysed data from 123 countries indicates that high levels of automobility — such as those seen in Aotearoa/New Zealand-result from, and further entrench, social inequities [5].

More recently the New Zealand government has outlined its intention to undertake a just transition to a more sustainable transport system that, among other things, reduces inequities $[6,7]$. Aotearoa/New Zealand was also one of the first countries in the world to shift its national accounting measures away from a focus on economic growth, with the recent release of the first national Wellbeing Budget. This budget introduces alternative measures of progress that represent life quality for people living in Aotearoa/New Zealand, and covers twelve domains of wellbeing developed using the Capabilities Approach to Wellbeing [8]. Other policy tools such as the Living Standards Framework developed by the New Zealand Treasury, on which the Wellbeing Budget is based, are also underpinned by the Capabilities Approach to Wellbeing [9]. The Capabilities Approach to Wellbeing was initially developed by Amartya Sen and it places capabilities and functionings ('beings' and 'doings') as the central components of wellbeing. In this approach wellbeing is conceptualised as the ability to live a life one has reason to value [10].

Furthermore, the New Zealand government has recently passed the Climate Change Response (Zero Carbon) Amendment Act 2019, which commits the government to shifting the country to zero net carbon emissions by 2050, implying a large and rapid transformation in the road transport system, which is responsible for $19 \%$ of the country's total gross carbon emissions [11].

Transport policy in Aotearoa/New Zealand, as with any policy in this country, should also give effect to the Treaty of Waitangi (the treaty between the Crown and Māori-the indigenous peoples of Aotearoa). While this Treaty outlines the rights of indigenous peoples in Aotearoa/New Zealand, the principles contained within it are equally applicable to other disadvantaged groups. The Treaty is commonly interpreted as stipulating three guiding principles for governance: developing partnerships with Māori, ensuring Māori participation, and actively protecting the interests and rights of Māori [12]. The New Zealand Government is also a signatory to the United Nations Declaration on the Rights of Indigenous Peoples and it has an obligation under this to ensure indigenous wellbeing and engagement 
in decision making as well as to address socioeconomic inequities for Māori [13,14]. However, this shift to a focus on equity, sustainability and broader ideas of wellbeing is currently not fully reflected in transport policy, which is only gradually shifting away from traditional car-dominated ideas (see Box 1).

We describe a theoretical framework for distributive justice that is based on the Capabilities Approach, and apply this by, first, clarifying the concepts of equity and wellbeing and, second, providing guidance for the achievement of the goals of reducing inequities related to the transport system and shifting the policy focus from economic growth to wellbeing.

We use examples related to Aotearoa/New Zealand, highlighting the ways in which this framework can complement the conceptions of wellbeing held by Māori. By doing so, we aim to develop a distributive justice framework that can work with a diverse range of views of wellbeing and which can be possibly generalised to other cultures. The interpretation of this framework from a Māori perspective, taking a Kaupapa Māori approach [15], is important, however, it is beyond the scope of this paper to provide an in-depth exploration of Māori (or other indigenous populations') views on wellbeing and the Capabilities Approach.

\section{Context: Transport, Wellbeing and Equity}

The influences of the transport system on people's wellbeing are pervasive but complex: they are both positive and negative; direct and indirect; and occur at a range of scales, including geographic and temporal [3]. Many of these affect health-through access to services such as healthcare, education, employment, shops, friends and family, and leisure activities [16,17], exposure to hazards (e.g. injury, air pollution) and opportunities for physical activity [18-20]. In addition, transport influences wellbeing through indirect mechanisms, such as its effect on housing availability and costs, time and opportunity costs, segregation and community cohesion, and carbon costs, both now and in the future $[3,21]$. These influences are often distributed unevenly, and there are many examples from around the world of people who are least able to use transport networks bearing the greatest costs, both economic and otherwise [3,22-26]. Different people also have different transport needs, and these needs change throughout their life. For example, an elderly person's use of the transport system may be very different to that of a young professional, which may be different again from that of a person with school-aged children, or a school-aged child themself.

It is clear that traditional transport policy methods-for example, transport demand modelling and narrow cost-benefit analysis-are not accounting for the full range of costs and benefits of transport, or the needs and demands of all groups in society [27-29]. However, due to the complexities of transport needs and outcomes (positive and negative) and different views on the ways in which inequities should be tackled, there is no straightforward prescription for transport improvements to address inequities [30].

Policies and actions to decarbonise the transport system can accentuate existing transport-related inequities, between current citizens, as well as between generations, or create new pathways to inequity [31-33]. However, the need for the transport system to reduce its environmental impact also provides an opportunity for us to look more critically at the system's equity outcomes and the ways in which these might be improved. As part of the effort to address transport-related inequities and their associated outcomes, it is clearly important to change transport systems so that costs and benefits are fairly distributed. This inevitably requires trade-offs to be made. It is important that a clear philosophical framework is employed to specify the ways in which these trade-offs can be made in a fair way.

Justice and equity have been discussed in the transport literature for many years in a range of ways, including in terms of sustainability, environmental impacts and injuries, funding and travel pricing mechanisms, and equitable access/accessibility and its related constructs (for the purposes of this paper, access/accessibility is broadly defined as "whether people can get to key services at reasonable cost, in reasonable time and with reasonable ease" [3] (p. 166). In order to avoid confusion 
with the word 'accessibility' in the disabilities literature we use the word 'access') $[3,22,34,35]$. There is also an evolving discussion around the ways in which distributive and other social justice theories might apply to transport and which ones may be most useful for transport policy [36]. Distributive justice theories can help to address the structural issues found in transport policy and planning by providing normative rules (i.e. what should and should not be done) to guide fair policy decisions. These theories aim to set out clearly what is important for wellbeing, and the ways in which those important things should be distributed fairly [37]. However, the discussion on the definition of transport or mobility justice within an alternative framework is evolving rapidly. Verlinghieri and Schwanen [36] note important limitations of the discussion to date, including a failure to recognise the importance of ensuring the fair participation of a diverse range of actors in policymaking, and a failure to recognise the influences of exogenous complex systems on the way in which people move and engage with transport systems.

Due to the equity and environmental issues that were already discussed, we argue that the market-orientated, neoliberal philosophical framework that has underpinned transport policy in the last 40 years in many car-oriented societies [38] has failed to provide just transport systems, and that it should be rethought [39]. In the next section, we briefly explore the ways in which distributive justice theories have been previously applied to transport policy. In Section 4, we look in more depth at the application of the Capabilities Approach, due to its current use in wider social policy and political ideology in a number of jurisdictions around the world, including Aotearoa/New Zealand, Germany, the United Kingdom, the European Union, the Organisation for Economic Co-operation and Development (OECD) and the United Nations [8,9,40-43]. We then propose a different application of the Capabilities Approach in order to guide transport policy makers on a broader range of equity issues in Section 5.1.

Finally, in Section 5.2, we develop a framework with which to apply theories of this kind in the transport setting. We treat the New Zealand transport system as a test case, focusing on the equity of the wellbeing impacts of recent transport policies. This framework shifts from what Verlinghieri and Schwanen refer to as a state-centric approach to transport equity, which focuses on the distribution of resources or capabilities across society, towards a society-centric transport justice approach, which focuses on addressing justice issues from the bottom up by broadening the typical application of distributive justice frameworks and incorporating fair procedure, broader temporal and spatial scales, and different world views [36,44].

\section{Transport and Distributive Justice Theories}

A number of scholars have shaped the discussion on distributive justice theories in transport research over recent years. Karel Martens has produced a substantial body of work on distributive justice relating to transport $[45,46]$. Martens's theory is based on work by prominent philosophers, particularly Walzer, Dworkin and Rawls. In his book 'Transport Justice: Designing Fair Transportation Systems' Martens settles on the concept of access as the main focus for fair transport policy, through the application of Walzer's Spheres of Justice (which argues that goods with a distinct social meaning need their own set of norms in order to establish a fair distribution). He then presents what a fair distribution of access should be, and the ways in which we can assess and address any shortfalls, based on Dworkin's theory on the equality of resources. Martens develops rules for fair transport policy decision-making processes that are designed to identify specific groups with insufficient access and guide the process of raising access levels for these groups to a fair level.

Martens's theory has been criticised for the way in which he has applied Walzer's and Dworkin's theories, and for the issues that may arise in real-world situations (for example, see Vanoutrive and Cooper [47] for a discussion of the issues of paternalism and production). However, from the perspective of this paper, the main limitation with Martens's theory is that it is exclusively focused on access and the fairness of its distribution. It does not consider other important areas of wellbeing-such as health impacts and effects on carbon mitigation—-that are inextricably linked to transport policy. 
Additionally, the theories used by Martens separate the components of wellbeing into separate spheres with separate rules governing their fair distribution. This conceptually constrains what is in reality a dynamic and complex system, with indirect interactions between transport and health, or transport and the environment. The isolation of specific areas of wellbeing in this way makes it difficult to conceptualise the ways in which transport policy decisions might affect the population as a whole, as well as different groups of people, and individuals' lives, in indirect and often unforeseen and unintended ways over time.

Transport geographers and mobilities researchers urge greater attention to be paid to broader power configurations [36] and the ways in which transport and mobility decisions are made. They also call for a re-orientation towards the consideration of the 'rights to the city' and rights to movement. This means the encouragement of co-creation and collective power to turn back the commodification of urban space and movement, rather than purely a redistribution of benefits and disadvantages across society or space $[36,44,48]$. As such, there has been a recent shift in research focus to broader considerations of transport justice and an expanded field of mobility justice, which not only looks at movement at urban or national levels, but also international travel, migration and the movement of resources and information at a global scale $[36,49]$.

While these developments have provided a more comprehensive view of social justice issues, they still do not illuminate the indirect systemic effects of transport policy, particularly the complex pathways to health impacts.

Theories based on the Capabilities Approach seem to offer more potential for the conceptualisation of linkages and interactions that are an integral part of all complex social-ecological systems [50], as well as providing guidance on procedural justice and power configurations [10]. However, to date these theories have not been developed in this way in the transport equity and justice fields. We argue that this lack of development is due to a narrow focus on specific transport-related capabilities, predominantly mobility and accessibility. Given that the Capabilities Approach fits with broader social policy and political ideologies in many highly motorised countries $[8,9,40,41,51]$, there is a pragmatic argument for the pursuit of a state-centric theoretical development of transport equity and justice, in the words of Verlinghieri and Schwanen [36], and the framing of transport justice in terms of this framework (i.e. to help integrate transport justice with current policymaking frameworks). The next section discusses the Capabilities Approach and the ways in which it has previously been applied to transport.

\section{Transport and the Capabilities Approach}

\subsection{The Fundamentals of the Capabilities Approach}

The Capabilities Approach is a normative framework that was developed by Amartya Sen, Martha Nussbaum and others, to conceptualise and evaluate influences on the wellbeing of people (when we talk about 'people' in this paper we mean both the individual and collective scales) as well as inequities in the distribution of these influences [10,51-53]. The capabilities approach is often used to conceptualise individual wellbeing, but is an equally valid conception of collective wellbeing [54,55]. It originates from the field of welfare economics, but has been applied to many areas over recent years. The focus of the Capabilities Approach is not what people have, but what they are able to do and be, and it defines wellbeing as people's ability to live a life they have reason to value. The important aspects of people's wellbeing are the sets of things from which they can choose to do and be (their capabilities), and the ways in which they value that which they end up doing and being (their functionings) [10]. Figure 1 provides a visual representation of the Capabilities Approach and the ways in which the various components relate to each other to influence wellbeing. 


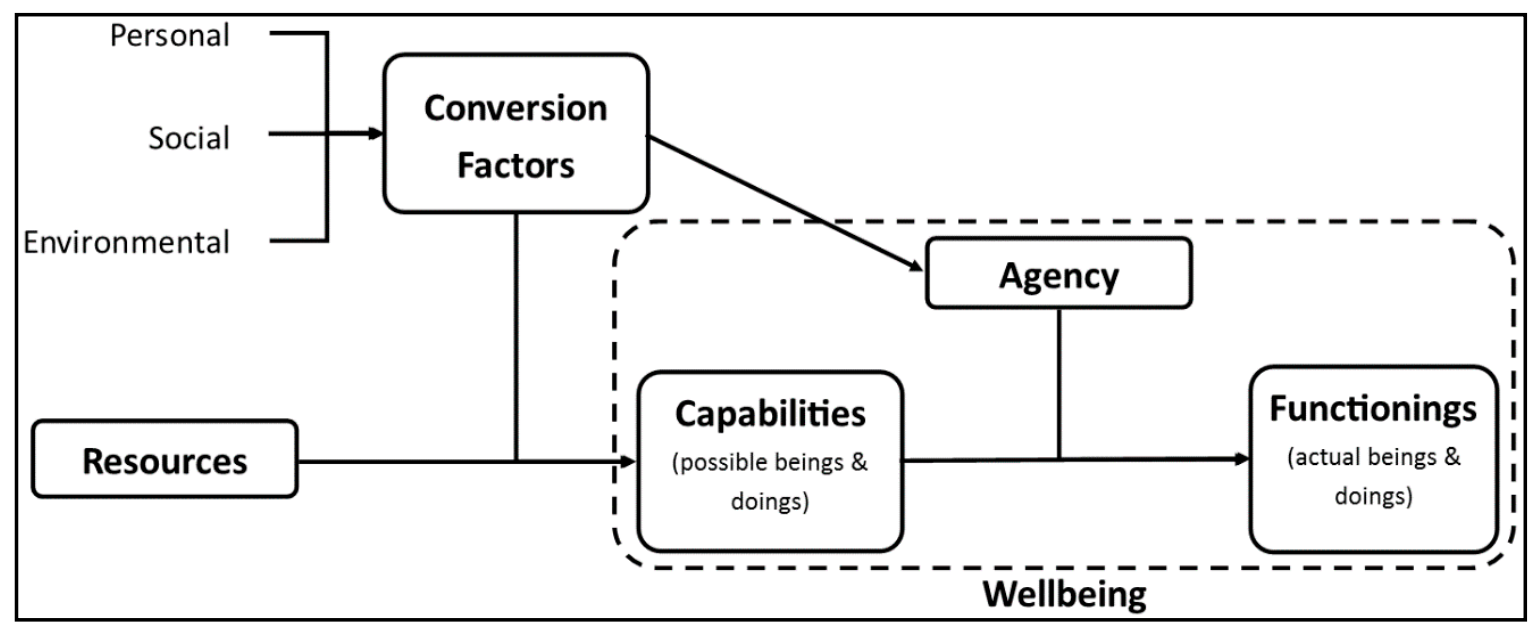

Figure 1. The Capabilities Approach to Wellbeing (adapted from [51]).

Agency is also a key component of the Capabilities Approach, in that it is important that people are able to choose from their sets of capabilities, the 'beings' and 'doings' they have reason to value. As such, it is not only the end result (the functionings) that is important for wellbeing, but whether people can freely choose the 'beings' and 'doings' they value, and whether they are able to achieve their vision of 'the good life' [51]. Agency is also affected by context, including economic, environmental and social factors such as community empowerment. For example, a person might value an environment free from air pollution and can afford to choose whether to use polluting technologies (e.g. diesel vehicles) or not, but that person's agency over living in a pollution-free environment is limited by the polluting behaviour of others (which they may or may not have agency over). The limitations on a person's agency imposed by others is captured in the Capabilities Approach as a social Conversion Factor, which is discussed in detail below.

Inequity arises when people's basic capabilities (those that are central to living a life they have reason to value), or their agency over these capabilities, are compromised due to personal and social circumstances, such as gender, ethnicity, wealth or social conventions. Therefore, the central concern of the Capabilities Approach, in terms of equity, is equality of opportunity, ensuring people have real freedom of choice over what they choose to be and do, whatever their circumstances [10]. In other words, differences in life outcomes should not be determined by (past or present) discrimination based on gender, ethnicity, disability or other personal and social circumstances. This often requires affirmative action to rebalance opportunities for the disadvantaged [56].

Although the Capabilities Approach clearly states that agency is central to equity and wellbeing, and that people should be free to choose their functionings, this freedom of choice should not apply to all decisions. Nussbaum [52] states that, while some freedoms are central to the concepts of wellbeing and social justice, other freedoms are harmful (e.g. everyone driving as fast as they wish) and some are less important. Certain key freedoms must be prioritised, while the protection of other freedoms depends on weighing up the costs and benefits of their maintenance. From this, Nussbaum has argued that a list of core capabilities, closely related to notions of human rights, that applies to all societies should be defined and protected, such as being able to move freely from place to place, having adequate education, being able to engage in social interaction, and being able to participate effectively in political decision-making, among others $[57,58]$. Nussbaum goes on to clarify the relationship between the Capabilities Approach and Human Rights. She explains that capabilities should be viewed as the things that secure fundamental rights to people: "The right to political participation, the right to religious free exercise, the right to free speech-these and others are all best thought of as secured to people only when the relevant capabilities to function are present" [52] (p. 37). Sen agrees with the view that the Capabilities Approach is concerned with the central capabilities that are fundamental for a basic quality of life, but has argued consistently that people in different communities should be free 
to define their own list of individual or collective capabilities that are important to them in order to avoid issues of paternalism and ideological or cultural imposition and to ensure community agency or empowerment, in line with Articles 3, 4, 8, 18 and 27 of the UN Declaration on the Rights of Indigenous Peoples $[14,59]$. However, both Sen and Nussbaum agree that freedom of choice and agency must be protected for the types of capabilities presented in Nussbaum's list. The freedoms that may justifiably be restricted include those that are of marginal or no benefit, and those which cause harm to others or to society as a whole. This includes the limitation of the freedoms of individuals when those freedoms violate the fundamental rights and freedoms of others, including the curtailing of individual freedoms for the benefit of the community or society as a whole. For example, speed limits on roads and the mandated wearing of seatbelts are acceptable restrictions under Nussbaum's and Sen's approaches.

The Capabilities Approach varies from the theories of justice proposed by Rawls, Dworkin and other philosophers in that the focus of the former is on what people are able to do and be, rather than solely on the resources that they have. In the Capabilities Approach resources are still important, but are considered to be an input into capabilities, rather than the primary focus. The other key components of the Capabilities Approach are Conversion Factors. These are the personal, social and environmental influences on people's ability to convert resources into capabilities and the influences on their agency in choosing what to do and be. This is where the social and structural determinants of health and wellbeing are located, along with the institutions, technologies, practices, rules and norms, public services and personal characteristics that affect people's capabilities and decisions $[51,60,61]$.

\subsection{Transport Applications of the Capabilities Approach}

The Capabilities Approach has been applied to transport policy in two main ways. First, it has been used as a framework in order to evaluate the equity of transport projects or policies [37]. Beyazit [62] presented a broad methodology for the use of the Capabilities Approach to evaluate social justice in transport research and Hananel and Berechman [63] assessed the social justice implications of specific transport policies in King County, Washington, USA. Hickman et al. [64] used the approach to evaluate the equity impacts of access to transport in Manila, and Nazari-Adli, Chowdhury, and Shiftan [65] compared the fairness of public transport systems in Auckland, Brisbane, Perth and Vancouver. Ryan, Wretstrand, and Schmidt [66] also used the Capabilities Approach to assess the contribution of public transport to the wellbeing of older people in Stockholm.

The Capabilities Approach has also been applied to transport policy by defining a transport-specific capability. Like Martens in his Theory of Transportation Justice, most writers have reasoned that access is primary [37,67]. Recently, Pereira et al. [37] proposed that augmenting this approach with principles from John Rawls' Theory of Justice might be useful to strengthen the normative aspects of this approach and provide further guidance to transport policy. These principles are, first, that no policy should violate basic rights and liberties, even if it improves access for others (for example, people's health should not be unduly harmed by policies that are intended to increase access) [37]. This complements Nussbaum's argument that the freedoms protected by the Capabilities Approach are only those that are central to wellbeing and do not include freedoms that may be inconsequential, or bad for the person, or others in society [52], e.g., it is reasonable to restrict freedoms by lowering speed limits on roads near schools in order to protect the lives of children. The second principle that Pereira et al. [37] apply to the Capabilities Approach is Rawls' Difference Principle [68]. This principle implies that fair transport policies are those that improve access levels particularly for the most disadvantaged in society if there is a differential, rather than universal, effect. Pereira et al. [37] point out that this Difference Principle allows for the setting of upper levels of access if further increases would result in a reduction in wellbeing for those who have the least. For example, restrictions might be placed on increases in car access in order to ensure continued access for public or active transport. Pereira et al. [37] also highlight a number of concordances between Rawls' Theory of Justice and Sen's Capability Approach that are important for just transport policy. These are that the equality of opportunity is 
central to social (and transport) justice and that both frameworks support a minimum threshold of access and other components (capabilities or resources) of wellbeing.

This approach was further developed by Nazari-Adli, Chowdhury and Shiftan [65] by incorporating Pereira's transport justice principles and Martens's Theory of Transportation Justice with the rights and spatial approach of Soja [69]. From this Nazari-Adli et al. provide four rules for transit planning: the right to access the city should not be violated; a minimum level of transit accessibility should be defined; transit accessibility should be improved for low income people; and the distribution of transit services should be assessed spatially, mapping accessibility and income levels together in order to identify priority low accessibility and low income areas for investment.

The main limitation of the current applications of the Capabilities Approach, and distributive justice theories in general, is that they do not provide guidance for policy makers on the biggest issues facing the transport system today: the mitigation of climate change (and other environmental/sustainability concerns) and the social and health impacts of transport. They focus on the identification of an important but specific capability (predominantly access or mobility) that applies to transport, which they argue should be the main focus of transport planners/policymakers $[63,65,67,70]$. Access is clearly important for any consideration of transport justice, not least because it provides a spatial dimension, which many measures of inequity or injustice do not. However, access cannot and should not be the only focus of transport policy makers. Approaches to transport justice need to provide sufficient guidance to policy makers on the ways to address the substantial problems of reducing carbon and the way to deal with the health and wellbeing impacts of transport in equitable ways. The next section argues that transport policy makers could receive more ethical and normative guidance from these distributive justice approaches (specifically those based on the Capabilities Approach) if the application of these theories to transport was shifted from a single capability, such as access, to the consideration of a wider set of transport policy outcomes which contribute to wellbeing. This can be achieved by taking a broader systems view of transport that better covers the range of important indirect costs and externalities while establishing a clearer focus on equity and wellbeing.

\section{Alternative Application of the Capabilities Approach to Transport}

\subsection{Transport Policy as a Social Conversion Factor}

This section presents an application of the Capabilities Approach to transport policy by conceptualising transport policy as a social Conversion Factor, in addition to focusing on transport policy acting on the capability of access (see Figure 2). This shift in focus expands the various pathways through which transport policy can influence wellbeing and explicitly lays out the role of transport policy in counteracting negative influences on a wide range of capabilities and, ultimately, wellbeing. 


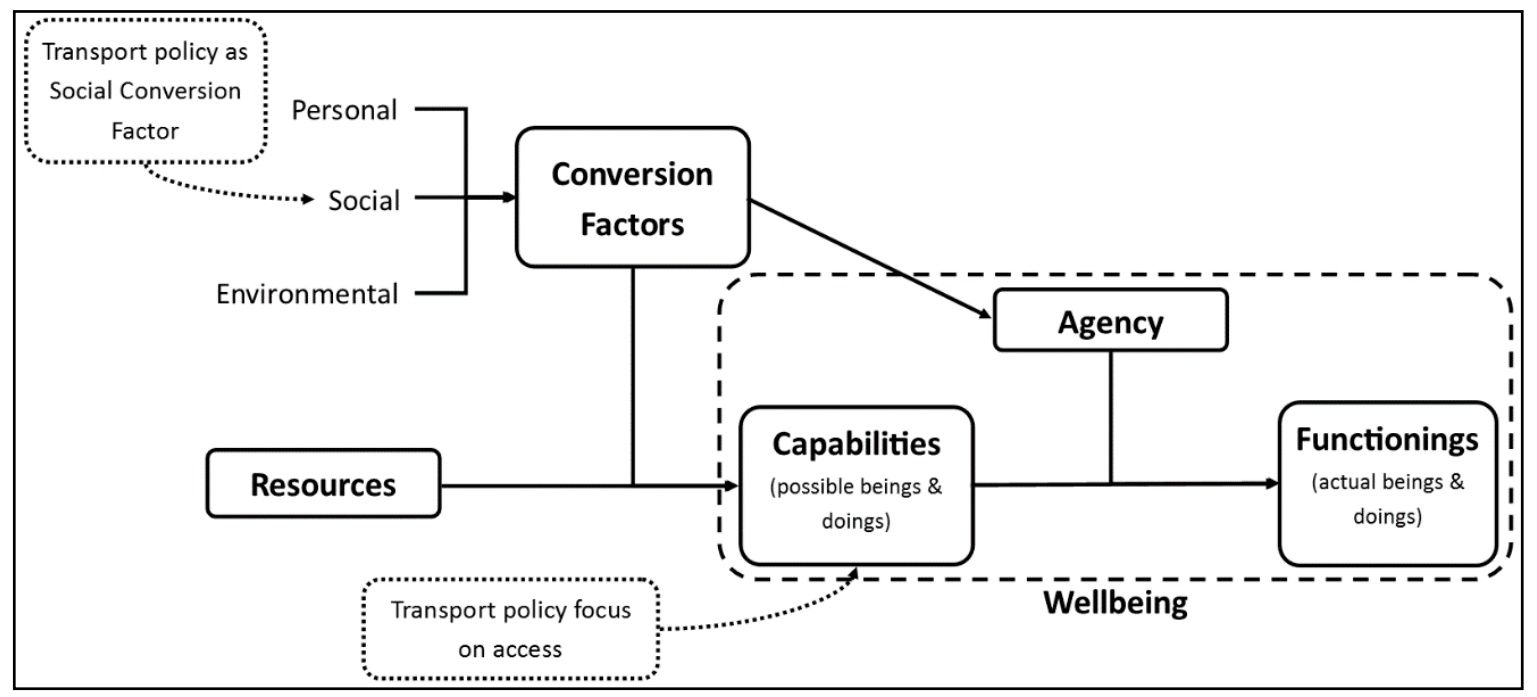

Figure 2. Different points of focus for transport policy.

As mentioned in Section 4.1, Conversion Factors are the contextual factors that influence a person's ability to convert resources and opportunities into capabilities and functionings, and ultimately a life that a person has reason to value. These factors can be positive or negative (i.e. increase or decrease capabilities), interact with each other in complex ways, and can be grouped as personal, social, or environmental [51]. Public policy sits in the social Conversion Factor category. The role of public policy is to provide a positive influence on capabilities in order to counteract negative personal, social and environmental Conversion Factors that would otherwise reduce people's capabilities [40,71]. This aligns with Rawls" claim that "justice is the first virtue of social institutions" [68]. As Goerne [60] puts it, "Conversion factors are the place within the capability-approach to take into account all these structural effects which determine what and the ways in which commodities can be turned into functionings". [60] (p. 8) In other words, many of the social and structural determinants of health that are a key focus of public health [2], are conceptualised in the Capabilities Approach as Conversion Factors $[40,60]$. Goerne goes on to state that " ... conversion factors ... [are] the place to locate the mechanisms which either alleviate or produce social inequalities" [60] (p. 17). This is clearly a major point of focus where society can both create and address inequities. Thinking in terms of capabilities is useful for the identification of inequities, but to understand the ways in which those inequities have come about, and what action may best address them, a focus on Conversion Factors is required.

A further benefit to this focus on Conversion Factors is that it does not require a defined list of capabilities (or an individual capability, such as access) to be imposed on others. As discussed in Section 4, Sen has argued consistently that each community should be free to define their own list of capabilities [59]. The focus on Conversion Factors opens up the policy framework to other worldviews by allowing people to define what is important to them and their culture [72]. In Aotearoa/New Zealand the government is obligated under the Treaty of Waitangi and as a signatory to the UN Declaration on the Rights of Indigenous Peoples to, among other things, ensure the self-determination of indigenous peoples and recognise their traditional knowledge, culture and collective rights and freedoms $[13,14]$. In keeping with these responsibilities, capabilities could be defined that fit within Te Ao Māori (the Māori Worldview), structured around the established conceptions of Māori wellbeing, such as the five domains of Ngā Pou Mauriora [72], or the four goals of Te Pae Māhutonga [73], which have been identified as important factors in the relationship between transport and Māori wellbeing [74]. Durie also describes two essential processes for the achievement of these goals, specifically Nga Manukura (leadership) and Te Mana Whakahaere (autonomy), which complement the concept of agency in the Capabilities Approach [73]. There is still room to have access as a capability, if this is chosen as a basic requirement for wellbeing by society, but taking a Conversion Factors approach to transport 
policy creates the possibility of authentically incorporating Māori wellbeing concepts into established national-level policy frameworks. This would indicate a stronger commitment to the meeting of the nation's obligations under the Treaty of Waitangi and would give fuller effect to the guiding principles of partnership, participation and active protection of Māori in the transport system. Other authors have commented on the links between the Capabilities Approach and Māori views on wellbeing, as well as the importance of process for Māori wellbeing [72,75]. Following the principles of self-determination, leadership and autonomy, this important and complex emerging area of research should be led by indigenous researchers and, as such, is beyond what can be achieved in this paper.

Conceiving of transport policy as a social Conversion Factor that in turn affects people's capabilities gives a clearer focus on the ways in which transport acts as a social determinant of health and impacts on wellbeing through a range of capabilities, including employment, education, access, health, and democratic participation, among others. The interconnected nature of the transport system with other urban systems and broader contributors to wellbeing becomes more apparent. In contrast, a narrow focus on either access or mobility makes it harder to be cognisant of the other direct and indirect health, environmental and wellbeing impacts of the transport system. This narrow focus also obscures some of the duties of transport planners to consider externalities, such as the environmental impacts, sustainability and health impacts that affect other crucial aspects of wellbeing.

It is worth noting that Ryan, Wretstrand and Schmidt [66], Vecchio [76], and Verlinghieri and Schwanen [36] have raised the concept of Conversion Factors with regard to transport, but focused on the Conversion Factors that facilitate or hinder the conversion of transport resources or commodities into capabilities, along the lines of Sen's and Robeyn's example of the ability to use a bicycle for transport [51,77].

\subsection{A Broader Normative Framework for Equitable Transport Policy}

In the previous Section 5.1, we have argued that viewing transport policy as a Conversion Factor, rather than as something that acts on a single capability, gives greater direction to policy makers and makes fuller use of the normative and philosophical framework of the Capabilities Approach developed by Sen and Nussbaum. As outlined in Section 4.2, Pereira et al [37] proposed the combination of the Capabilities Approach with the normative principles of Rawls' Theory of Justice in order to guide equitable transport policy, with access being defined as the capability of primary concern to transport policy makers. We have argued that a focus on a single capability, such as access (as in Figure 2) would not make the best use of the Capabilities Approach. However, Pereira and colleagues' combination of the Capabilities Approach and Rawls' Theory of Justice provides a useable framework for fair transport policy.

To build on the transport justice framework presented by Pereira et al., we now present a set of four principles that combines the Capabilities Approach with the normative principles of Rawls, focusing on transport policy as a social Conversion Factor. These principles emphasise the importance of accounting for the negative impacts and externalities of transport and the importance of understanding who is benefiting from a specific policy (or the transport system as a whole) and who is bearing the cost and whether this distribution is fair or not $[10,37,52,68]$.

The four principles proposed by this broader approach to transport justice with respect to transport policy are that:

1. The role of public policy is to act as a positive Conversion Factor that enhances capabilities and counteracts negative Conversion Factors (influences), while protecting the basic rights and freedoms.

2. The effects of policies and the actions of people should not violate basic rights and freedoms of others including those of future generations.

3. Transport policy should promote equality of opportunity; hence policy should focus on capabilities and not solely on outcomes. 
4. Fair policies are those that improve capabilities at least for the most disadvantaged in society. Both minimum and maximum thresholds of capabilities can be set to achieve this.

Working through some of the implications of the above principles gives a clearer picture of what this framework might mean for equity and transport policy.

The application of these principles would ensure that policy makers take into account the direct and indirect, positive and negative impacts of their actions. This would draw attention to the ways in which decisions impact on people's access as well as on people's health, employment and education possibilities and other indirect capabilities (e.g. the opportunity costs of long commutes on the ability to exercise for better health or socialising, or transport's impacts on housing costs).

The application of Rawls' Liberty Principle (that one's actions should not restrict the rights of others) to future generations as well as current generations strengthens the position of the Capabilities Approach on environmental issues and addresses the sustainability of transport policy $[78,79]$. For example, future capabilities should not be diminished by the effect of transport emissions on the climate. The restriction of the consideration of rights and freedoms to those basic freedoms, the ones that are "good and important" [52], allows for the restriction of people's freedoms when the exercise of those freedoms is inconsequential, or bad for wellbeing, or when the results of exercising those freedoms are bad for society as a whole. Nussbaum [52] gives the example of compelling people to wear helmets while riding motorbikes; another transport example is congestion charging to reduce motor vehicle traffic in order to avoid health-damaging air pollution, or the removal of car parking to make way for safer cycle lanes. This is also justified by Pereira et al. [37] if the restriction car use for some, specifically those who are better off, would lead to greater access for others (the disadvantaged) by, for example, improving public or active transport. Another example might be the restriction of the level of public investment in infrastructure for private electric vehicles in order to provide electric buses and bicycles, promoting public and active transport at lower public expense and with lower environmental costs [80].

Having the Capabilities Approach as the central, explicit framework to guide decision-making leads to policies that improve wellbeing by increasing people's capabilities and freedoms, while ensuring fair process. This contrasts with the evaluation of policy impacts in narrow income or economic growth terms [71]. In order to demonstrate the possible implications of this approach to high-level transport policy, Box 1 gives an overview of the national-level transport policy direction of Aotearoa/New Zealand over the last 40 years and outlines the implications of the proposed alternative approach and the ways in which this may have altered the transport system that has evolved over this time. 
Box 1. Transport policy: economic growth vs wellbeing and equity.

Aotearoa/New Zealand has been on the road to car-dependence since the 1950s. During this period, there was a shift away from planned, compact cities built around public transport and an increased focus on 'US style' motorway building in its largest cities [81]. Alongside this, Māori were actively encouraged to move to cities and settle in new state housing developments as a labour force for growing urban areas. The policy at the time was to disperse Māori households throughout cities, creating socially dislocated communities and further increasing pressure on urban transport infrastructure [82]. At the same time the government moved towards a 'user-pays' method of funding road building with the creation of the National Road Fund [83]. The fund is sourced from road user charges, fuel taxes and vehicle licensing fees and is now called the National Land Transport Fund (NLTF). While this fund is now allowed to be used to fund projects (and policing) that improve the wider transport network (including rail) in the interests of the public, it is often seen as a 'ring-fenced' fund for the improvement of the roads for those who pay for it. The road freight and private motor vehicle lobbies often cite the former Fund arrangements (funding largely from fuel excise and road user charges) to pressure governments to increase spending on roads $[84,85]$.

Since the 1980s, New Zealand government policy, consistent with that of many OECD countries, has focused on the achievement of economic growth and efficiency, defined as meeting demand in the most cost-effective way with minimal state intervention [38]. In line with this, transport policy has followed the idea of allowing the private market—as much as possible - to guide transport supply. Many areas of transport were privatised in the 1980s and 1990s, including rail, aviation, maritime, road freight and public transport. The government continued to provide roading infrastructure through the hypothecated NLTF [86]. The automobility paradigm gained ground, car ownership per capita rose to be the highest in the OECD [87], and the movement of private vehicles and truck freight were given priority above all other modes. Transport policy and planning relied heavily on 'predict and provide' modelling to guide transport investments, reinforcing past trends and further entrenching a dependency on car use $[4,88]$.

By and large, transport policy in NZ has not accounted for the broader impacts of transport decisions on society and the environment (in particular carbon emissions), the ways in which these are distributed across society, and the ways in which the transport system interacts with land use. Until recently, little effort was made to provide healthy options for travel around cities, privileging private motor vehicles and reinforcing barriers to public and active transport. This further exacerbated public health issues including air pollution, road traffic injuries, obesity-related diseases and societal issues $[89,90]$. These have had a greater impact on Māori and those who are less well-off and therefore contributed to increasing inequities [24,91-95].

If instead, transport policy had explicitly focused on providing equitable improvements in wellbeing it is likely that Aotearoa/New Zealand would have a very different transport system to the one it currently has and perhaps a different funding model. Transport policy focused on equity would, first, make it more likely that the transport system-and people's use of it—would not violate others' basic rights and freedoms. This includes people's right to safety and health, and the rights of current and future generations to environmental sustainability. Second, it would support the central principles of social justice and equality of opportunity, and focus on the capabilities of people, rather than solely on outcomes (which, in the case of mode choice are often constrained by the transport system provided). Third, it would address inequities through fair policies designed to improve the capabilities of the least well-off in society. Finally, transport policy, as public policy, would be required to provide a positive influence on capabilities and counteract negative personal, social and environmental Conversion Factors, ensuring that the broader systemic influences of transport, and the influences of other systems on transport, are taken into consideration.

These different philosophical approaches would likely have resulted in a transport system that was explicitly planned to have the least possible negative impact on the environment. It would aim to minimise negative impacts on people's health and provide opportunities for healthy behaviours. It would aim to preserve people's transport options, while ensuring that the opportunities of the least well off are prioritised. It would also ensure that people have high levels of access to all of the things that are vital to living a life that they have reason to value (such as social interaction, education and employment), as well as improving their capabilities directly (for example, by improving their health).

In order to further illustrate these points, Table 1 presents examples of the questions that transport policy makers would be asking themselves given different approaches to justice and wellbeing. In order to avoid the choice of an arbitrary list of capabilities, we have used areas of wellbeing that have been chosen by the New Zealand Treasury (the lead advisor to the Government on economic and fiscal policy). The Treasury has developed a Living Standards Framework that is based on the Capabilities Approach to Wellbeing [96], and has been used to deliver the first national Wellbeing Budget underpinned by an explicit shift away from a focus on the growth of Gross Domestic Product (GDP) [97]. This Framework sets out 12 Domains of Wellbeing, 11 of which can be directly related 
to central Capabilities and Functionings [8]. We have selected four of these for illustrative purposes. These four examples show the ways in which a Conversion Factor approach can expand transport policymaking to cover the indirect influences of the transport system on capabilities other than access. They highlight the importance of designing transport policy that acts positively on a range of capabilities. Table 1 also shows the interdependent relationship between transport policy and land-use, health and environmental policies. These examples show the ways in which the transport policy process can facilitate agency and empowerment through more appropriate civic engagement and participation on top of providing access to civic engagement opportunities. 
Table 1. Wellbeing implications of different transport policy approaches.

\begin{tabular}{|c|c|c|c|}
\hline $\begin{array}{l}\text { Living Standards } \\
\text { Framework } \\
\text { Wellbeing Domain }\end{array}$ & $\begin{array}{l}\text { Questions for Transport Policy when } \\
\text { Focusing on Access }\end{array}$ & $\begin{array}{l}\text { Questions for Transport Policy when } \\
\text { Viewed as a Social Conversion Factor }\end{array}$ & Examples when Viewed as a Social Conversion Factor \\
\hline Health & $\begin{array}{l}\text { Does this policy provide fair access to health } \\
\text { services and health promoting activities? } \\
\text { Does one group's access have unfair impact on } \\
\text { other people's health? }\end{array}$ & $\begin{array}{l}\text { Does this transport policy fairly contribute to } \\
\text { the creation of health, directly and indirectly? } \\
\text { Does the transport policy maintain the ability } \\
\text { of future generations to achieve good health? }\end{array}$ & $\begin{array}{l}\text { An electric and a diesel bus provide the same access; } \\
\text { however they have very different effects on air pollution \& } \\
\text { health. } \\
\text { Building a new traffic lane may increase overall access over } \\
\text { a cycle lane (at least in the short term), however a cycle lane } \\
\text { may provide more health benefit in terms of physical } \\
\text { activity and road safety improvements, and better options } \\
\text { for those who have difficulty affording a motor vehicle, or } \\
\text { who cannot drive. }\end{array}$ \\
\hline Environment & $\begin{array}{l}\text { Does this policy provide fair access to the } \\
\text { natural environment (e.g. greenspace or } \\
\text { waterway)? } \\
\text { Does people's access degrade or improve the } \\
\text { environment? }\end{array}$ & $\begin{array}{l}\text { Does this transport policy contribute to } \\
\text { sustaining or degrading the environment, its } \\
\text { ability to provide for people, and people's } \\
\text { relationship to the environment, particularly } \\
\text { for those worse off and future generations? }\end{array}$ & $\begin{array}{l}\text { A new motorway may increase access to a regional park; } \\
\text { however, it may also increase car use and carbon emissions, } \\
\text { which contribute to climate change and global } \\
\text { environmental damage. Climate change may ultimately } \\
\text { result in the loss or degradation of the regional park } \\
\text { ecosystem. Looking at it from this perspective one may } \\
\text { choose to increase access to the park through public } \\
\text { transport systems or even not at all, it may be decided to } \\
\text { invest in improving the quality of local green and blue } \\
\text { spaces (i.e. the solution may not even be a transport one) }\end{array}$ \\
\hline $\begin{array}{l}\text { Civic engagement \& } \\
\text { governance }\end{array}$ & $\begin{array}{l}\text { Does this provide fair access to opportunities } \\
\text { to engage with democracy (e.g. access to } \\
\text { voting booths, Council meetings, iwi/ tribal } \\
\text { decision-making etc.)? }\end{array}$ & $\begin{array}{l}\text { Is the transport decision making process open } \\
\text { and democratic, in a way that encourages } \\
\text { participation and engagement? }\end{array}$ & $\begin{array}{l}\text { The framing of transport decision-making in technocratic } \\
\text { terms based on complex transport and economic modelling } \\
\text { may contribute to scepticism about urban governance and } \\
\text { disengagement of many who are concerned most about } \\
\text { non-quantifiable urban wellbeing outcomes, rather than } \\
\text { indices of transport and economic activity. It also tends to } \\
\text { ensure power is held with technocrats rather than } \\
\text { providing mechanisms for well-informed public } \\
\text { participation by a variety of groups. }\end{array}$ \\
\hline
\end{tabular}




\section{Conclusions}

Taking a broader view of the application of distributive justice theory to transport allows for greater utilisation of the philosophies of these theories, as well as clearer conceptualisation of the impacts of transport on wellbeing and guidance for actions to improve transport justice. This, in turn, helps to address some of the shortcomings of the distributive justice approaches to transport justice highlighted by Verlinghieri and Schwanen [36] and to provide a more pragmatic framework for transport policy makers.

This paper presented an internationally relevant theoretical framework to guide transport policy makers through a fair transition to a more sustainable and equitable transport system. The viewing of transport policy as a social Conversion Factor has reconceptualised the way in which the Capabilities Approach is applied to transport policy. This aligns with and facilitates a systems view of transport [98-100] by highlighting the multiple ways in which transport policies can influence wellbeing across society, and the multiple ways in which transport is influenced by other policies, such as those influencing urban form. This makes it easier for policy makers to take into account the dynamic non-linearities and feedback loops that are a part of all complex social-ecological systems [50]. This perspective helps to shift transport justice and the policymaking process away from a limited consideration of the distribution of resources towards the consideration of broader power structures and fair process in transport policymaking. A brief summary is presented in Box 2. By using a framework that is already embedded in the current social policy paradigm, the uptake of this alternative approach should be feasible within existing institutions.

The adaptation of Rawlsian principles to the transport context, as proposed by Pereira et al [37], clarifies the normative guidance transport policy makers might follow to create fairer processes, decisions and outcomes that are more equitable for both current and future generations.

Box 2. Summary: A new approach to fairness in transport policy.

- Previous application of the Capabilities Approach to transport policy:

- $\quad$ Defined one transport-specific capability (access) to be the focus of policy

- Incorporated ideas from Rawls' Theory of Justice to create a set of principles for transport justice:

1. Basic rights and liberties should not be violated to improve access for others;

2. A minimum level of access should be defined and guaranteed. Higher levels of access may need to be constrained if further increases will reduce access for others;

3. Policies should prioritise improving access for vulnerable and disadvantaged groups to reduce inequities $[37,65]$.

- $\quad$ Did not consider:

- $\quad$ Agency or empowerment

- Transport policy's role in enhancing or limiting other capabilities (e.g. health)

- Transport policy's interactions with other policy areas (other than land-use), such as environmental or health policy

- A new approach, using Social Conversion Factors to extend the Capabilities Approach to transport policy:

- Enables a broader perspective of the influences of transport policy on many capabilities besides access

- Allows communities to define their own list of capabilities, which may or may not include a transport-specific capability such as access

- Considers agency and emphasises the importance of fair process and just decision making

- $\quad$ Provides stronger normative guidance - public policy should act positively and counteract negative influences on capabilities

- $\quad$ Encourages the combination of transport policy with other policy areas to fit with holistic approaches to fairness and wellbeing 
While we have introduced into this framework the relevance of Māori wellbeing concepts for transport policy, we have not critically explored this in depth. In the international context, each country will have their own entrenched systems of inequity arising from systemic and historic factors, as well as their own indigenous populations. It is critical that future work assesses the ways in which this framework can better serve these populations. When exploring the further application of this framework to the Aotearoa/New Zealand setting it will be important to look in more depth at the ways in which this approach may complement and learn from Māori wellbeing frameworks. It is also vital that future work looks at whether (and how) this approach may contribute to addressing the impacts of colonisation on Māori wellbeing. The role that land-use and transport policy has played and continues to play in the process of colonisation raises the important issue of whether indigenous perspectives might offer more informed guidance. Expanding the literature on transport and wellbeing from a Māori perspective is important and could likely support the transport policy process to better promote the health and wellbeing of indigenous New Zealanders.

Further work is needed in order to explore and understand the many links between transport policy and wellbeing using systems thinking and modelling. In order to fully realise the benefits of this different approach and to speed up the much-needed transition away from the current system of automobility, it is also important to investigate the ways in which these ideas can be fully integrated into the processes of existing governing institutions, what actions may facilitate the acceptance of these alternative approaches to transport policy development and what barriers stand in the way.

An approach to policymaking built on these distributive justice theories can contribute to the wider shift currently observed among many governments around the world away from a reliance solely on GDP, or economic activity measures of progress, to the use of broader measures of wellbeing. This approach also aligns well with other international guidelines to improve sustainability, health and wellbeing and can clarify the ways in which transport policy might contribute to the achievement of these global challenges, e.g., the Sustainable Development Goals set by the United Nations.

Author Contributions: Conceptualization, E.R., C.S., A.W. and M.K.; investigation, E.R.; writing-original draft preparation, E.R.; writing-review and editing, C.S., A.W., P.H.-C., A.M, J.H., R.C., A.M.W. and M.K; supervision, C.S., A.W. and M.K.; project administration, E.R.; funding acquisition, E.R. All authors have read and agreed to the published version of the manuscript.

Funding: This research was funded by a University of Otago PhD Scholarship awarded to E.R.

Conflicts of Interest: The authors declare no conflict of interest. The funders had no role in the design of the study; in the collection, analyses, or interpretation of data; in the writing of the manuscript, or in the decision to publish the results.

\section{References}

1. United Nations. Reduced Inequalities: Why it Matters; United Nations: New York, NY, USA, 2018.

2. Commission on the Social Determinants of Health. Final Report. Closing the Gap in a Generation: Health Equity through Action on the Social Determinants of Health; World Health Organization: Geneva, Switzerland, 2008.

3. Banister, D. Inequality in Transport; Alexandrine Press: Marcham, UK, 2018; p. 272.

4. Urry, J. The 'System' of Automobility. Theory Cult. Soc. 2004, 21, 25-39. [CrossRef]

5. Valenzuela-Levi, N. Why do more unequal countries spend more on private vehicles? Evidence and implications for the future of cities. Sustain. Cities Soc. 2018, 43, 384-394. [CrossRef]

6. Ministry of Transport. A Framework for Shaping our Transport System: Transport Outcomes and Mode Neutrality; New Zealand Government: Wellington, New Zealand, 2018.

7. Woods, M. Just Transition to a Low Emissions Economy: Strategic Discussion Cabinet Paper. Office of the Minister of Energy and Resources, New Zealand Government: Wellington, New Zealand, 2018.

8. The Treasury. Our People, Our Country, Our Future. Living Standards Framework: Background and Future Work; New Zealand Government: Wellington, New Zealand, 2018. Available online: https://treasury.govt.nz/ publications/tp/living-standards-framework-background-and-future-work (accessed on 3 December 2020).

9. Durand, M. The OECD Better Life Initiative: How's Life? And the Measurement of Well-Being. Rev. Income Wealth 2015, 61, 4-17. [CrossRef] 
10. Sen, A. The idea of Justice; Harvard University Press: Cambridge, MA, USA, 2009.

11. Ministry for the Environment. New Zealand's Greenhouse Gas Inventory 1990-2018; New Zealand Government: Wellington, New Zealand, 2020; Volume 1.

12. Royal Commission on Social Policy. The April Report Volume 2: Future Directions; Royal Commission on Social Policy: Wellington, New Zealand, 1988.

13. Human Rights Commission. Human Rights in New Zealand 2010: Chapter 4 Human Rights and the Treaty of Waitangi; Human Rights Commission: Wellington, New Zealand, 2010.

14. United Nations General Assembly. Resolution 61/295 United Nations Declaration on the Rights of Indigenous Peoples; A/RES/61/295 (2 October 2007); United Nations: New York, NY, USA, 2007.

15. Hoskins, T.K.; Jones, A. Critical Conversations in Kaupapa Māori; Huia Publishers: Wellington, New Zealand, 2017.

16. van Wee, B. Accessible accessibility research challenges. J. Transp. Geogr. 2016, 51, 9-16. [CrossRef]

17. Lucas, K. Transport and social exclusion: Where are we now? Transp. Policy (Oxf) 2012, 20, 105-113. [CrossRef]

18. Khreis, H.; Warsow, K.M.; Verlinghieri, E.; Guzman, A.; Pellecuer, L.; Ferreira, A.; Jones, I.; Heinen, E.; Rojas-Rueda, D.; Mueller, N.; et al. The health impacts of traffic-related exposures in urban areas: Understanding real effects, underlying driving forces and co-producing future directions. J. Transp. Health 2016, 3, 249-267. [CrossRef]

19. Woodcock, J.; Edwards, P.; Tonne, C.; Armstrong, B.G.; Ashiru, O.; Banister, D.; Beevers, S.; Chalabi, Z.; Chowdhury, Z.; Cohen, A.; et al. Public health benefits of strategies to reduce greenhouse-gas emissions: Urban land transport. Lancet 2009, 374, 1930-1943. [CrossRef]

20. Litman, T. Transportation and Public Health. Annu. Rev. Public Health 2013, 34, 217-233. [CrossRef]

21. Barton, H. Land use planning and health and well-being. Land Use Policy 2009, 26, S115-S123. [CrossRef]

22. Gössling, S. Urban transport justice. J. Transp. Geogr. 2016, 54, 1-9. [CrossRef]

23. Mackett, R.L. The health implications of inequalities in travel. J. Transp. Health 2014, 1, 202-209. [CrossRef]

24. Hosking, J.; Ameratunga, S.; Exeter, D.; Stewart, J.; Bell, A. Ethnic, socioeconomic and geographical inequalities in road traffic injury rates in the Auckland region. Aust. N. Z. J. Public Health 2013, 37, 162-167. [CrossRef] [PubMed]

25. Rachele, J.N.; Learnihan, V.; Badland, H.M.; Mavoa, S.; Turrell, G.; Giles-Corti, B. Neighbourhood socioeconomic and transport disadvantage: The potential to reduce social inequities in health through transport. J. Transp. Health 2017, 7, 256-263. [CrossRef]

26. Hwang, J.; Joh, K.; Woo, A. Social inequalities in child pedestrian traffic injuries: Differences in neighborhood built environments near schools in Austin, TX, USA. J. Transp. Health 2017, 6, 40-49. [CrossRef]

27. Martens, K.; Di Ciommo, F. Travel time savings, accessibility gains and equity effects in cost-benefit analysis. Transp. Rev. 2017, 37, 152-169. [CrossRef]

28. Martens, K.; Golub, A.; Robinson, G. A justice-theoretic approach to the distribution of transportation benefits: Implications for transportation planning practice in the United States. Transp. Res. Part A Policy Pract. 2012, 46, 684-695. [CrossRef]

29. van Wee, B. How suitable is CBA for the ex-ante evaluation of transport projects and policies? A discussion from the perspective of ethics. Transp. Policy (Oxf) 2012, 19, 1-7. [CrossRef]

30. Nordbakke, S.; Schwanen, T. Well-being and Mobility: A Theoretical Framework and Literature Review Focusing on Older People. Mobilities 2014, 9, 104-129. [CrossRef]

31. Hickman, R.; Ashiru, O.; Banister, D. Transitions to low carbon transport futures: Strategic conversations from London and Delhi. J. Transp. Geogr. 2011, 19, 1553-1562. [CrossRef]

32. Giles-Corti, B.; Vernez-Moudon, A.; Reis, R.; Turrell, G.; Dannenberg, A.L.; Badland, H.; Foster, S.; Lowe, M.; Sallis, J.F.; Stevenson, M.; et al. City planning and population health: A global challenge. Lancet 2016, 388, 2912-2924. [CrossRef]

33. Levinson, D. Equity effects of road pricing: A review. Transp. Rev. 2010, 30, 33-57. [CrossRef]

34. Di Ciommo, F.; Shiftan, Y. Transport equity analysis. Transp. Rev. 2017, 37, 139-151. [CrossRef]

35. Duran-Rodas, D.; Villeneuve, D.; Pereira, F.C.; Wulfhorst, G. How fair is the allocation of bike-sharing infrastructure? Framework for a qualitative and quantitative spatial fairness assessment. Transp. Res. Part A: Policy Pract. 2020, 140, 299-319. [CrossRef]

36. Verlinghieri, E.; Schwanen, T. Transport and mobility justice: Evolving discussions. J. Transp. Geogr. 2020, 87, 102798. [CrossRef] 
37. Pereira, R.H.M.; Schwanen, T.; Banister, D. Distributive justice and equity in transportation. Transp. Rev. 2017, 37, 170-191. [CrossRef]

38. McDermott, P.; Toleman, R.; Lee, R.W. Recent and Future Transport Policy Planning in New Zealand. Transp Res. Rec. 1997, 1606, 9-16. [CrossRef]

39. Walks, A. Stopping the 'War on the Car': Neoliberalism, Fordism, and the Politics of Automobility in Toronto. Mobilities 2015, 10, 402-422. [CrossRef]

40. Brunner, R.; Watson, N. What Can the Capabilities Approach Add to Policy Analysis in High-Income Countries? 2015. Available online: http://whatworksscotland.ac.uk/wp-content/uploads/2015/03/ workingpaper-capabilities-approach.pdf (accessed on 3 December 2020).

41. The European Commission. Beyond GDP: Measuring Progress, True Wealth, and Well-Being. Available online: https://ec.europa.eu/environment/beyond_gdp/index_en.html (accessed on 18 August 2020).

42. Arndt, C.; Volkert, J. The Capability Approach: A Framework for Official German Poverty and Wealth Reports. J. Human Dev. Capabil. 2011, 12, 311-337. [CrossRef]

43. Osmani, S.R. The Capability Approach and Human Development: Some Reflections; United Nations Development Porgramme: New York, NY, USA, 2016.

44. Karner, A.; London, J.; Rowangould, D.; Manaugh, K. From Transportation Equity to Transportation Justice: Within, Through, and Beyond the State. J. Plan. Lit. 2020, 35, 440-459. [CrossRef]

45. Martens, K. Transport Justice: Designing fair Transportation Systems; Routledge: New York, NY, USA, 2017.

46. Martens, K. Justice in transport as justice in accessibility: Applying Walzer's 'Spheres of Justice' to the transport sector. Transportation 2012, 39, 1035-1053. [CrossRef]

47. Vanoutrive, T.; Cooper, E. How just is transportation justice theory? The issues of paternalism and production. Transp. Res. Part A Policy Pract. 2019, 122, 112-119. [CrossRef]

48. Harvey, D. The Right to the City. New Left Rev. 2008, 53, 23-40.

49. Sheller, M. Theorising mobility justice. Tempo soc. 2018, 30, 17-34. [CrossRef]

50. Walker, B.; Gunderson, L.; Kinzig, A.; Folke, C.; Carpenter, S.; Schultz, L. A Handful of Heuristics and Some Propositions for Understanding Resilience in Social-Ecological Systems. Ecol. Soc. 2006, 11. [CrossRef]

51. Robeyns, I. The Capability Approach: A theoretical survey. J. Human Dev. Capabil. 2005, 6, 93-117. [CrossRef]

52. Nussbaum, M. Capabilities as Fundamental Entitlements: Sen and Social Justice. Fem. Econ. 2003, 9, 33-59. [CrossRef]

53. Sen, A. Human rights and capabilities. J. Human Dev. Capabil. 2005, 6, 151-166. [CrossRef]

54. Stewart, F. Groups and Capabilities. J. Human Dev. Capabil. 2005, 6, 185-204. [CrossRef]

55. Tonon, G. Communities and Capabilities. J. Human Dev. Capabil. 2018, 19, 121-125. [CrossRef]

56. United Nations Department of Economic and Social Affairs. Development Issues No. 1: Concepts of Inequality; United Nations: New York, NY, USA, 2015.

57. Nussbaum, M. Human rights and human capabilities. Harv. Hum. Rts. J. 2007, 20, 21.

58. Nussbaum, M. Capabilities and human rights. Fordham L. Rev. 1997, 66, 273.

59. Sen, A. Capabilities, Lists, and Public Reason: Continuing the Conversation. Fem. Econ. 2004, 10, 77-80. [CrossRef]

60. Goerne, A. The Capability Approach in Social Policy Analysis-Yet Another Concept? In REC-WP Working Papers on the Reconciliation of Work and Welfare in Europe No. 03-2010; University of Edinburgh: Edinburgh, UK, 2010. [CrossRef]

61. Sen, A. Well-Being, Capability and Public Policy. G. Econ. Ann. Econ. 1994, 53, 333-347.

62. Beyazit, E. Evaluating social justice in transport: Lessons to be learned from the capability approach. Transp. Rev. 2011, 31, 117-134. [CrossRef]

63. Hananel, R.; Berechman, J. Justice and transportation decision-making: The capabilities approach. Transp. Policy (Oxf) 2016, 49, 78-85. [CrossRef]

64. Hickman, R.; Cao, M.; Mella Lira, B.; Fillone, A.; Bienvenido Biona, J. Understanding Capabilities, Functionings and Travel in High and Low Income Neighbourhoods in Manila. Soc. Incl. 2017, 5, 161-174. [CrossRef]

65. Nazari-Adli, S.; Chowdhury, S.; Shiftan, Y. Justice in public transport systems: A comparative study of Auckland, Brisbane, Perth and Vancouver. Cities 2019, 90, 88-99. [CrossRef]

66. Ryan, J.; Wretstrand, A.; Schmidt, S.M. Exploring public transport as an element of older persons' mobility: A Capability Approach perspective. J. Transp. Geogr. 2015, 48, 105-114. [CrossRef] 
67. Smith, N.; Hirsch, D.; Davis, A. Accessibility and capability: The minimum transport needs and costs of rural households. J. Transp. Geogr. 2012, 21, 93-101. [CrossRef]

68. Rawls, J. A Theory of Justice; Harvard University Press: Cambridge, MA, USA, 2009.

69. Soja, E.W. Seeking Spatial Justice; University of Minnesota Press: Minneapolis, MN, USA, 2010; Volume 16.

70. Pereira, R.H.M. Future accessibility impacts of transport policy scenarios: Equity and sensitivity to travel time thresholds for Bus Rapid Transit expansion in Rio de Janeiro. J. Transp.Geogr. 2019, 74, 321-332. [CrossRef]

71. Trani, J.-F.; Bakhshi, P.; Bellanca, N.; Biggeri, M.; Marchetta, F. Disabilities through the Capability Approach lens: Implications for public policies. Alter 2011, 5, 143-157. [CrossRef]

72. Waa, A.M.; Pearson, A.L.; Ryks, J.L. Premature mortality resilience and wellbeing within urban Māori communities. Health Place 2017, 43, 49-56. [CrossRef] [PubMed]

73. Durie, M. Te Pae Māhutonga: A model for Māori health promotion. HPF Newsl. 1999, 49, $2-5$.

74. Raerino, K.; Macmillan, A.K.; Jones, R.G. Indigenous Māori perspectives on urban transport patterns linked to health and wellbeing. Health Place 2013, 23, 54-62. [CrossRef]

75. Waa, A.M.; Ryks, J.L.; Livesey, B.; Kilgour, J. Responding to the challenges: Māori and urban development. In Cities in New Zealand: Preferences, Patterns and Possibilities; Howden-Chapman, P., Early, L., Ombler, J., Eds.; Steele Roberts Aotearoa: Wellington, New Zealand, 2017; pp. 15-28.

76. Vecchio, G. Microstories of everyday mobilities and opportunities in Bogotá: A tool for bringing capabilities into urban mobility planning. J. Transp. Geogr. 2020, 83, 102652. [CrossRef]

77. Dang, A.-T. Amartya Sen's Capability Approach: A Framework for Well-Being Evaluation and Policy Analysis? Rev. Soc. Econ. 2014, 72, 460-484. [CrossRef]

78. Sen, A. The Ends and Means of Sustainability. J. Human Dev. Capabil. 2013, 14, 6-20. [CrossRef]

79. Watene, K. Nussbaum's Capability Approach and Future Generations. J. Hum. Dev. Capabil. 2013, 14, 21-39. [CrossRef]

80. Henderson, J. EVs Are Not the Answer: A Mobility Justice Critique of Electric Vehicle Transitions. Ann. Am. Assoc. Geogr. 2020, 110, 1-18. [CrossRef]

81. Coleman, A. Transport infrastructure, lock-out and urban form: Highway development in Auckland and the United States. Policy Q. 2010, 6, 23-27. [CrossRef]

82. Woods, M. Integrating the nation: Gendering Māori Urbanisation and Integration, 1942-1969. Ph.D. Thesis, University of Canterbury, Christchurch, New Zealand, 2002.

83. Mees, P.; Dodson, J. The American Heresy: Half a century of transport planning in Auckland. In Geography: A Spatial Odyssey: Proceedings of The Third Joint Conference of the New Zealand Geographical Society and the Institute of Australian Geographers, Dunedin, New Zealand, 1 February 2001; Holland, P., Stephenson, F., Wearing, A., Eds.; Brebner Print: Hamilton, New Zealand, 2001; pp. 279-287.

84. Road Transport Forum. Transport Infrastructure must be a Focus for New Government [Press Release]. Scoop Media. 2017. Available online: https://www.scoop.co.nz/stories/BU1710/S00616/transport-infrastructuremust-be-a-focus-for-new-government.htm (accessed on 3 December 2020).

85. Lowrie, M. Greater Auckland: Fixing the National Land Transport Fund. 2019. Available online: https://www. greaterauckland.org.nz/2017/10/25/fixing-national-land-transport-fund/ (accessed on 3 December 2020).

86. Lee, R.W.; Rivasplata, C.R. Metropolitan transportation planning in the 1990s: Comparisons and contrasts in New Zealand, Chile and California. Transp. Policy (Oxf) 2001, 8, 47-61. [CrossRef]

87. OECD. OECD Environmental Performance Reviews: New Zealand 2017; OECD Publishing: Paris, France, 2017.

88. Docherty, I.; Shaw, J.; Gather, M. State intervention in contemporary transport. J. Transp. Geogr. 2004, 12, 257-264. [CrossRef]

89. Randal, E.; Keall, M.; Shaw, C.; Russell, M.; Woodward, A.; Chapman, R.; Howden-Chapman, P. Why New Zealand transport policy needs to encourage walking and cycling. In Cities in New Zealand: Preferences, Patterns and Possibilities, Howden-Chapman, P., Early, L., Ombler, J., Eds.; Steele Roberts Aotearoa: Wellington, New Zealand, 2017; pp. 107-114.

90. Howden-Chapman, P.; Hales, S.; Chapman, R.; Shaw, C. Improving air quality: Co-benefits for the urban system. Air Qual. Clim. Chang. 2011, 45, 19. 
91. Kuschel, G.; Metcalfe, J.; Wilton, E.; Guria, J.; Hales, S.; Rolfe, K.; Woodward, A. Updated Health and Air Pollution in New Zealand Study (HAPINZ), Volume 1: Summary Report; Health Research Council of New Zealand, Ministry of Transport, Ministry for the Environment and the New Zealand Transport Agency: Wellington, New Zealand, 2012; pp. 1-44. Available online: https://www.mfe.govt.nz/sites/default/files/media/Air/ updated-health-and-air-pollution-new-zealand-study-summary-report.pdf (accessed on 3 December 2020).

92. Kingham, S.; Pearce, J.; Zawar-Reza, P. Driven to injustice? Environmental justice and vehicle pollution in Christchurch, New Zealand. Transp. Res. D: Transp. Environ. 2007, 12, 254-263. [CrossRef]

93. Hales, S.; Blakely, T.; Woodward, A. Air pollution and mortality in New Zealand: Cohort study. J. Epidemiol. Community Health 2012, 66, 468-473. [CrossRef] [PubMed]

94. Collins, D.C.A.; Kearns, R.A. Geographies of inequality: Child pedestrian injury and walking school buses in Auckland, New Zealand. Soc. Sci. Med. 2005, 60, 61-69. [CrossRef]

95. Rose, E.; Witten, K.; McCreanor, T. Transport related social exclusion in New Zealand: Evidence and challenges. Kōtuitui 2009, 4, 191-203. [CrossRef]

96. Johnson, J.; Carter, K.N. Increasing Equity Background Paper: Treasury's Living Standards Framework Papers; Treasury, T., Ed.; New Zealand Government: Wellington, New Zealand, 2015.

97. Government of New Zealand. The Wellbeing Budget 2019; The Treasury: Wellington, New Zealand, 2019.

98. Rees, D.; Stephenson, J.; Hopkins, D.; Doering, A. Exploring stability and change in transport systems: Combining Delphi and system dynamics approaches. Transportation 2017, 44, 789-805. [CrossRef]

99. Abbas, K.A.; Bell, M.G.H. System dynamics applicability to transportation modeling. Transp. Res. Part A Policy Pract. 1994, 28, 373-390. [CrossRef]

100. Whitmarsh, L. How useful is the Multi-Level Perspective for transport and sustainability research? J. Transp. Geogr. 2012, 24, 483-487. [CrossRef]

Publisher's Note: MDPI stays neutral with regard to jurisdictional claims in published maps and institutional affiliations. 